\title{
An Integrated Approach for Source Apportionment and Health Risk Assessment of Heavy Metals in Subtropical Agricultural Soils, Eastern China
}

\author{
Ping Li ${ }^{1}$, Tao $\mathrm{Wu}^{1}{ }^{1}$, Guojun Jiang ${ }^{1}$, Lijie Pu ${ }^{2}$, Yan $\mathrm{Li}^{3}$, Jianzhen Zhang ${ }^{1}$, Fei Xu ${ }^{4}$ and Xuefeng Xie ${ }^{1,5, *(D)}$ \\ 1 College of Geography and Environmental Sciences, Zhejiang Normal University, Jinhua 321004, China; \\ Lipingzjnu@126.com (P.L.); twu@zjnu.cn (T.W.); jgj@zjnu.cn (G.J.); zjz@zjnu.cn (J.Z.) \\ 2 School of Geography and Ocean Science, Nanjing University, Nanjing 210023, China; ljpu@nju.edu.cn \\ 3 Co-Innovation Center for the Sustainable Forestry in Southern China, College of Forestry, Nanjing Forestry \\ University, Nanjing 210037, China; lyle@njfu.edu.cn \\ 4 Institute of Land and Urban-Rural Development, Zhejiang University of Finance \& Economics, \\ Hangzhou 310018, China; xufei16@zufe.edu.cn \\ 5 Key Laboratory of the Coastal Zone Exploitation and Protection, Ministry of Natural Resources, \\ Nanjing 210023, China \\ * Correspondence: xiexuefeng@zjnu.cn
}

\section{check for} updates

Citation: Li, P.; Wu, T.; Jiang, G.; Pu, L.; Li, Y.; Zhang, J.; Xu, F.; Xie, X. An Integrated Approach for Source Apportionment and Health Risk

Assessment of Heavy Metals in Subtropical Agricultural Soils, Eastern China. Land 2021, 10, 1016. https://doi.org/10.3390/ land 10101016

Academic Editor: Claude Hammecker

Received: 13 August 2021

Accepted: 22 September 2021

Published: 28 September 2021

Publisher's Note: MDPI stays neutral with regard to jurisdictional claims in published maps and institutional affiliations.

Copyright: (c) 2021 by the authors. Licensee MDPI, Basel, Switzerland. This article is an open access article distributed under the terms and conditions of the Creative Commons Attribution (CC BY) license (https:// creativecommons.org/licenses/by/ $4.0 /)$.

\begin{abstract}
Unreasonable human activities may cause the accumulation of heavy metals (HMs) in the agricultural soil, which will ultimately threaten the quality of soil environment, the safety of agricultural products, and human health. Therefore, the accumulation characteristics, potential sources, and health risks of HMs in agricultural soils in China's subtropical regions were investigated. The mean $\mathrm{Hg}, \mathrm{Cu}, \mathrm{Zn}, \mathrm{Pb}$, and $\mathrm{Cd}$ concentrations of agricultural soil in Jinhua City have exceeded the corresponding background values of Zhejiang Province, while the mean concentrations of determined $8 \mathrm{HMs}$ were less than their corresponding risk-screening values for soil contamination of agricultural land in China. The spatial distribution of $\mathrm{As}, \mathrm{Cr}, \mathrm{Ni}, \mathrm{Cu}$, and $\mathrm{Pb}$ were generally distributed in large patches, and $\mathrm{Hg}, \mathrm{Zn}$, and $\mathrm{Cd}$ were generally sporadically distributed. A positive definite matrix factor analysis (PMF) model had better performance than an absolute principal component-multiple linear regression (APCS-MLR) model in the identification of major sources of soil HMs, as it revealed higher $\mathrm{R}^{2}$ value $(0.81-0.99)$ and lower prediction error $(-0.93-0.25 \%)$. The noncarcinogenic risks (HI) of the $8 \mathrm{HMs}$ to adults and children were within the acceptable range, while the carcinogenic risk (RI) of children has exceeded the safety threshold, which needs to be addressed by relevant departments. The PMF based human health risk assessment model indicated that industrial sources contributed the highest risk to HI (32.92\% and 30.47\%) and RI (60.74\% and 61.5\%) for adults and children, followed by agricultural sources $(21.34 \%, 29.31 \%$ and $32.94 \% 33.19 \%)$. Therefore, integrated environmental management should be implemented to control and reduce the accumulation of soil HMs from agricultural and industrial sources.
\end{abstract}

Keywords: soil heavy metals; positive definite matrix factor analysis; absolute principal componentmultiple linear regression; health risk assessment

\section{Introduction}

Heavy metals (HMs) in soil are characterized by high toxicity, nondegradability, weak mobility, and strong bioaccumulation [1,2]. With rapid urbanization, HMs pollution in agricultural soil caused by anthropogenic activities is becoming increasingly prominent and has become a global issue [3-6]. The difference between soil parent material and soil acidity and alkalinity is an important factor affecting the natural source of HMs. The subtropical red soil region is an important agricultural production base, as well as the most serious soil acidification area in China [7]. Soil acidification can not only lead to the leaching of nutrients [8] but also greatly improve the mobility and bioavailability of HMs [9,10]. The 
accumulation of HMs in agricultural soil can not only degrade soil structure and function, and thus reduce the quality and quantity of crop yield, but also posing considerable risks to human health via ingestion, inhalation, and skin contact [11,12]. Generally, soil HMs mainly originate from natural sources and anthropogenic sources. The former is mainly derived from soil parent material and the soil formation process $[13,14]$, while the latter are associated with industrial emissions and discharge, coal combustion, atmospheric deposition, vehicle exhaust, and unreasonable agricultural inputs $[12,15,16]$. Therefore, accurately identifying the potential sources of HMs in subtropical agricultural soil and determining the risks to human health is essential for local prevention and remediation of soil HMs pollution is important.

Receptor models are commonly used for identifying the sources of a specific pollutant and quantitatively estimating the contributions of each source at certain receptor locations $[17,18]$. Various receptor models (for instance, absolute principal component scores-multiple linear regression (APCS-MLR) and positive matrix factorization (PMF)) have been widely applied for source apportionment of soil HMs. Compared with the traditional principal component analysis, APCS-MLR introduces a sample point with zero content, and then the multiple linear regression of the source can identify specific emission sources and quantify each emission influences [18]. PMF model considers the uncertainty and non-negative constraints of the data, which not only identify the number of soil HMs pollution sources and the contribution rate of each pollution source but also quantitatively identify the contribution rate of each pollution source to each HMs $[13,19,20]$. Due to the complex sources of soil HMs, the accuracy of the source-analyzed receptor model is affected by both sample errors and modeling errors and the result of individual model is difficult to verify [21]. Although many studies have conducted in-depth analyses on the sources of soil HMs [11,22], few studies compared the effects of multiple receptor models for source apportionment of HMs in subtropical agricultural soils.

Some HMs will carry human blood through breathing, skin contact, diet intake, etc., and enter various organs and tissues of the human body along with blood circulation. When the HMs in the human body accumulate to a certain level, it will cause respiratory diseases, myocardial infarction (and other diseases), and serious consequences such as various cancers [23]. Presently, the risks of HMs to human health (carcinogenic risk and noncarcinogenic risk) have been received with wide concern [24-26]. However, the constituents of HMs varied from different sources, and the toxicities of various HMs were different; therefore, the human health risk posed by the highest source of HM concentrations is not necessarily the greatest $[4,25]$. Nevertheless, it is limiting to quantitatively determine the contribution of pollution sources of HMs in agricultural soils to human health risks. Therefore, an integrated approach combining human health risk assessment model with PMF model was proposed to quantitative human health risks from different sources of HMs and determine priority control sources in this study.

The subtropical region of eastern China has a suitable climate and adequate water and heat conditions, and is considered one of the important food bases in the Yangtze River Delta. Over the past 20 years, unreasonable human activities have led to the accumulation of HMs in the agricultural soils, which have eventually grown to threaten the soil quality and safety of agricultural products [27-31]. Therefore, the identification of HM pollution sources and health risks in this region is important for the remediation of agricultural soils in subtropical regions. The objectives of this study were to: (1) characterize the concentration and spatial distribution of agricultural soil HMs in Jinhua City, subtropical China; (2) compare the performance of APCS-MLR and the PMF model in the identification of potential sources and quantitation of the contribution of each source to soil HMs; and (3) establish an integrated health risk model to quantitatively determine contribution of pollution sources of HMs to human health risks. 


\section{Materials and Methods}

\subsection{Study Area}

Jinhua City is located in the middle of Zhejiang Province $\left(28^{\circ} 32^{\prime}-29^{\circ} 41^{\prime} \mathrm{N}, 119^{\circ} 14^{\prime}-\right.$ $120^{\circ} 46^{\prime}$ E) and the south wing of Yangtze River Delta, covering an area of 10,942 $\mathrm{km}^{2}$ (Figure 1). Jinhua City belongs to the eastern part of Jinqu Basin, with high terrain in the north and south and low terrain in the middle. It is characterized by a subtropical monsoon climate, with an average annual temperature of $17.5^{\circ} \mathrm{C}$ and an average annual rainfall of $1424 \mathrm{~mm}$. The vegetation type in study area is mainly subtropical evergreen broad-leaved forest, and the soil types are diverse, including red soil, yellow soil, purple soil, lithologic soil, coarse bone soil, limestone soil, fluvo aquic soil, and paddy soil. The main land use types are shown in Figure S1. Jinhua is the fourth largest metropolitan area in Zhejiang Province, with a gross domestic product (GDP) of $4.56 \times 10^{11} \mathrm{CNY}$ and a population of 4.92 million. Among them, Yiwu City has the highest population density (1683 persons $\left./ \mathrm{km}^{2}\right)$, followed by Jindong District $\left(766\right.$ persons $/ \mathrm{km}^{2}$ ) and Wucheng District (688 persons $/ \mathrm{km}^{2}$ ). Jinhua has distinctive regional economic characteristics and several major industries, such as the medicine and chemical industry, food, automobile parts, building materials, the light industry, and textiles, all of which cluster in this region.

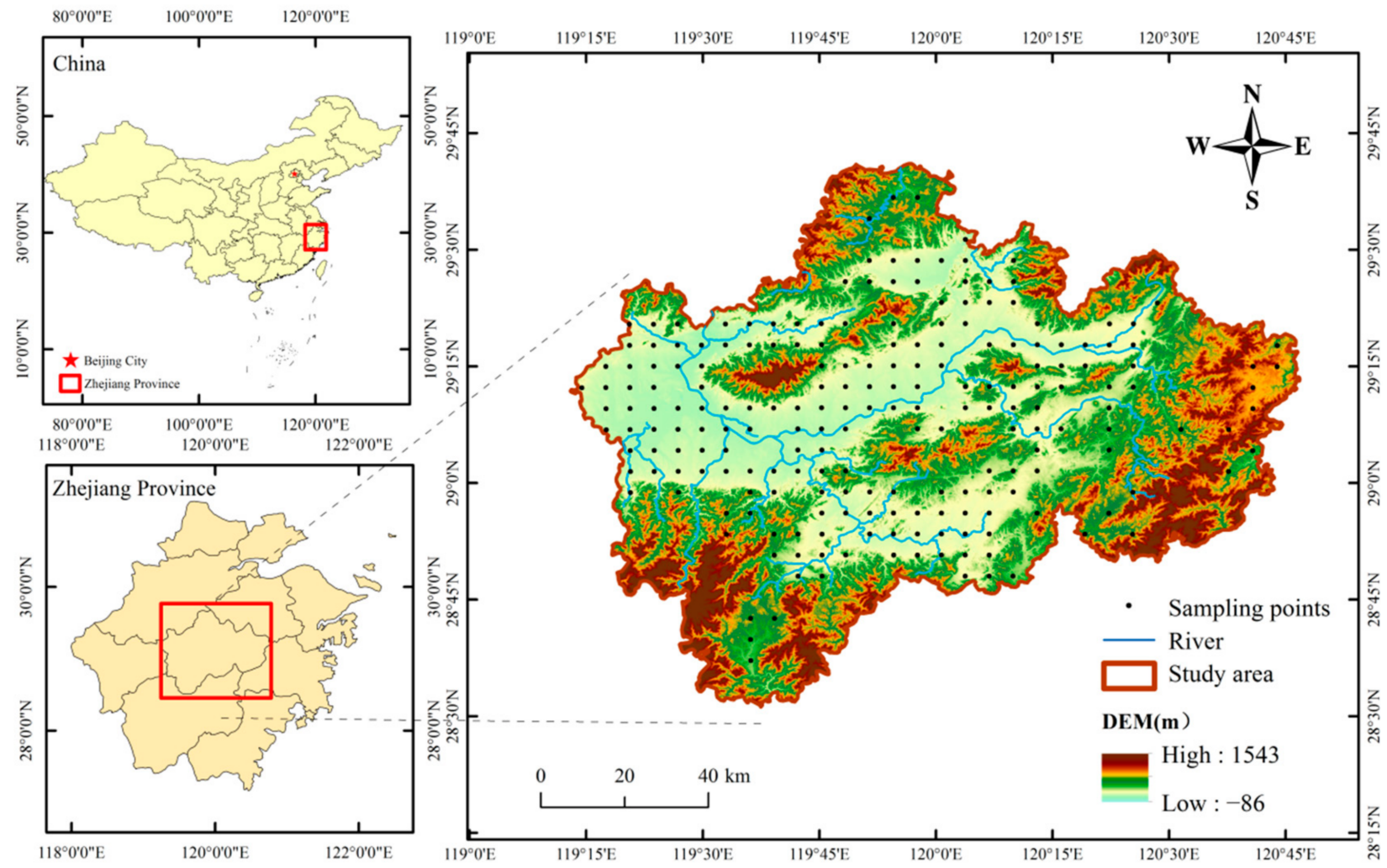

Figure 1. Location of the study area and soil sample sites. Digital elevation model (DEM).

\subsection{Sample Collection and Analysis}

Soil samples were selected by grid sampling method as suggested by previous study due to its uniform distribution, so as to provide an optimal geostatistical fitting effect [32-34]. Therefore, establishing a density of $25 \mathrm{~km}^{2}$ by using a $5 \mathrm{~km} \times 5 \mathrm{~km}$ grid were established to determine the sampling sites and a total of 209 topsoil $(0-20 \mathrm{~cm})$ samples were collected from agricultural land (Figure 1). At each site, five subsamples within a $100 \mathrm{~m}$ radius from the sampling site were collected and mixed into a composite sample, placed in a polyethylene bag, brought back to the laboratory. The original weight of each sample was guaranteed to exceed $1 \mathrm{~kg}$. Soils were air-dried, ground, and passed through a $0.149 \mathrm{~mm}$ sieve for testing the HMs before remove animal and plant residues. Soil $\mathrm{pH}$ was 
measured using a $\mathrm{pH}$ meter (Mettler Toledo, Switzerland) with a ratio of 1:2.5 soil to deionized water [35]. Soil $\mathrm{Cr}, \mathrm{Cd}, \mathrm{Cu}, \mathrm{Pb}, \mathrm{Ni}$, and $\mathrm{Zn}$ were digested with $\mathrm{HCl}-\mathrm{HNO}_{3}-\mathrm{HClO}_{4}$ on a hot plate and then determined by inductively coupled plasma emission spectrometer (ICP-AES); soil Hg and As were digested by aqua regia-digestion in water bath and measured using an inductively coupled plasma fluorescence spectrometer (ICP-AFS) [36]. All reagents used in the analyses were of premium grade. Quality control was carried out with the national soil standard reference material (GSS-24, Center of National Reference Materials of China), and $20 \%$ of the samples were randomly selected to test duplicate samples, the error was kept within 5\%, the recovery rate ranged from $81 \%$ to $109 \%$, and the measurement results were within the allowable range of error [37].

\subsection{Absolute Principal Component Score and Multiple Linear Regression}

Absolute principal component multiple linear regression is based on the principal component by introducing a variable with zero concentration and subtracting the factor fraction of the principal component from the variable with zero concentration, thus converting the factor fraction of the principal component into an absolute principal component factor fraction (which in turn identifies the pollution sources [22]), and then applying a multiple linear regression model to further determine the contribution of each source [18]. The equation are as follows:

$$
\begin{gathered}
Z_{i k}=\frac{X_{i k}-\overline{X_{i}}}{\sigma_{i}} \\
P_{j 0}=\frac{0-\overline{X_{i}}}{\sigma_{i}} \\
(A P C S)_{j k}=P_{j k}-P_{j 0} \\
X_{i k}=b_{0 i}+\sum_{p=1}^{n} b_{i j}(A P C S)_{j k}
\end{gathered}
$$

where $X_{i k}$ and $Z_{i k}$ represent the concentration and standardized concentration of the element $i$ at sampling site $k$, respectively; $X_{i}$ and $\sigma$ represent the average concentration and standard deviation of element $i$, respectively; $j$ is the number of factors; $P_{j k}$ is the factor $j$ affecting the total HMs in sample site $k ; P_{j 0}$ is the influence of factor $j$ on the concentration of sample site $k$ with zero concentration; $(A P C S)_{j k}$ is the factor score of transformed sample $k ; b_{0 i}$ represents the constant term of multiple linear regression; and $b_{i j}$ represents the coefficient of linear regression of factor $j$ on element $i$. The average value of $b_{i j}(A P C S)_{j k}$ at all sampling sites is used to represent the contribution of HMs sources.

\subsection{Positive Definite Matrix Factor Analysis}

The PMF model is a receptor model based on factor analysis for inferring the number and contribution of each source based on the situation of the pollution source $[18,21]$. The equation of the PMF 5.0 model is described in the USEPA PMF 5.0 guidance manual [38]. PMF model decomposes the original matrix into the source component spectrum matrix and source contribution rate matrix [12], expressed as:

$$
x_{i j}=\sum_{k=1}^{p} G_{i k} F_{k j}+e_{i j}
$$

where $x_{i j}$ is the concentration of the $j$ th element in the $i$ samples; $G_{i k}$ is the contribution of $k t h$ source to the $i t h$ sample; $F_{k j}$ is the concentration of the $j t h$ element in the source $k ; p$ is the number of source factors; $e_{i j}$ is the residual matrix obtained by minimizing the object function $Q$, which can be expressed as: 


$$
\begin{gathered}
Q=\sum_{i=1}^{n} \sum_{k=1}^{m}\left(\frac{e_{i j}}{U_{i j}}\right)^{2} \\
U_{i j}=\left\{\begin{array}{c}
\frac{5}{6} \times M D L, c<M D L \\
\sqrt{\left(R S D \times x_{i j}\right)^{2}+M D L^{2}, c \geq M D L}
\end{array}\right.
\end{gathered}
$$

where $Q$ is the square sum of the difference (i.e., $\left.e_{i j}\right)$ between the original dataset $\left(X_{i j}\right)$ and the PMF output $\left(G_{i k} F_{k j}\right) ; U_{i j}$ represents uncertainty; $R S D$ is the relative standard deviation; and $M D L$ is the detection limit of the species-specific method.

\subsection{Health Risk Assessment}

Human health risk assessment is estimated based on the exposure factor manual of USEPA, in which individuals are exposed to pollutants mainly through ingestion, respiratory inhalation and dermal contact $[39,40]$. According to the manual, the daily intake doses for adults and children under these three exposure routes are expressed as follows:

$$
\begin{gathered}
A D D_{\text {ing }}=C_{\text {soil }} \times \frac{I n g R \times C F \times E F \times E D}{B W \times A T_{n c / c a}} \\
A D D_{\text {ing }}=C_{\text {soil }} \times \frac{I n h R \times E F \times E D}{P E F \times B W \times A T_{n c / c a}} \\
A D D_{\text {derm }}=C_{\text {soil }} \times \frac{S A \times C F \times S L \times A B S \times E F \times E D}{B W \times A T_{n c / c a}}
\end{gathered}
$$

where $A D D_{\text {ing }}, A D D_{\text {inh }}$, and $A D D_{\text {derm }}$ represent the daily intake doses under three different exposure routes: ingestion, respiratory inhalation, and dermal contact, respectively; $C_{\text {soil }}$ represents the concentration of soil HMs. The definitions and values of exposure parameters of adult and child intake are shown in Table S1.

The noncarcinogenic risk (HI) and carcinogenic risk (RI) are calculated as follows:

$$
\begin{gathered}
H I=\sum_{i=1}^{n} \sum_{j=1}^{m} H Q_{i j}=\sum_{i=1}^{n} \sum_{j=1}^{m} \frac{A D D_{i j}}{R F D_{i j}} \\
H I=\sum_{i=1}^{n} \sum_{j=1}^{m} C R_{i j}=\sum_{i=1}^{n} \sum_{j=1}^{m} S F_{i} \times A D D_{i j}
\end{gathered}
$$

where $H Q$ is the ratio of the daily intake dose to the corresponding reference dose, which represents the non-carcinogenic risk effect of pollutants under a certain route; $H I$ represents the noncarcinogenic effect of pollutants under all routes; $C R$ is the daily dose multiplied by the corresponding slope factor, which represents the carcinogenic effect of pollutants in a certain way; $R I$ represents the carcinogenic effect of pollutants in all routes. The reference dose $(R f D)$ and slope factor $(S F)$ of the HMs applied in health risk assessment are shown in Table S2 [4,37].

\subsection{Statistical Analyses}

The descriptive statistics, K-S test, and APCS-MLR model were performed using SPSS 25.0 for Windows. The semivariogram modeling of the HMs was analyzed using GS + 9.0 for Windows, and the spatial distribution was analyzed using ordinary kriging interpolation in ArcGIS 10.2 for Windows. USEPA PMF 5.0 was conducted to quantify the HMs sources and contributions.

\section{Results and Discussion}

\subsection{Descriptive Statistics of Heavy Metals in Soil}

The descriptive statistics of $8 \mathrm{HMs}$ in agricultural soil from Jinhua City were summarized in Table 1 . The mean soil pH value was 5.34 , which indicated moderate acidity in 
study area. The mean concentrations of $\mathrm{As}, \mathrm{Cd}, \mathrm{Cr}, \mathrm{Cu}, \mathrm{Hg}, \mathrm{Ni}, \mathrm{Pb}$, and $\mathrm{Zn}$ in the agricultural soils of Jinhua City are 6.37, 0.18, 36.73, 18.6, 0.11, 11.95, 32.48 and $76.05 \mathrm{mg} \mathrm{kg}^{-1}$, respectively. Among them, the concentration of $\mathrm{Cd}, \mathrm{Hg}, \mathrm{Pb}$, and $\mathrm{Zn}$ exceeded their corresponding background values in Zhejiang and China, whereas the concentration of As, $\mathrm{Cr}$, and Ni did not. Moreover, the concentration of $\mathrm{Cu}$ was higher than its corresponding background values in Zhejiang, while lower than those in China. Particularly, the mean concentrations of $8 \mathrm{HMs}$ in Jinhua were less than their corresponding critical values in comparison to the risk control standard for soil contamination of agricultural land according to the Chinese Soil Quality Standard [41]. The coefficient of variation (CV) of soil HMs in the study area revealed that $\mathrm{Hg}(152.24 \%)$ had strong variability, which demonstrated higher discontinuity and a wider potential for anthropogenic effects [4]. The rest of the HMs were presented at a moderate variability and followed the order of $\mathrm{Ni}(98.55 \%)>\mathrm{Cr}(72.12 \%)>$ As $(57.56 \%)>\mathrm{Cu}(56.29 \%)>\mathrm{Cd}(53.07 \%)>\mathrm{Zn}(34.39 \%)>\mathrm{Pb}(25.59 \%)$.

Table 1. Statistical description of soil heavy metals concentrations in the agricultural land of Jinhua City $\left(\mathrm{mg} \mathrm{kg}^{-1}\right)$.

\begin{tabular}{cccccccccc}
\hline & $\mathbf{p H}$ & $\mathbf{A s}$ & $\mathbf{C d}$ & $\mathbf{C r}$ & $\mathbf{C u}$ & $\mathbf{H g}$ & $\mathbf{N i}$ & $\mathbf{P b}$ & $\mathbf{Z n}$ \\
\hline Min & 3.99 & 1.01 & 0.03 & 7.1 & 2.7 & 0.01 & 1.6 & 8.8 & 36.2 \\
Max & 8.15 & 25.17 & 0.68 & 217.1 & 97.3 & 2.14 & 131.8 & 59.7 & 226.9 \\
Mean & 5.34 & 6.37 & 0.18 & 36.73 & 18.6 & 0.11 & 11.95 & 32.48 & 76.05 \\
S.D & 0.78 & 3.67 & 0.1 & 26.49 & 10.47 & 0.16 & 11.78 & 8.31 & 26.15 \\
CV (\%) & 14.61 & 57.56 & 53.07 & 72.12 & 56.29 & 152.24 & 98.55 & 25.59 & 34.39 \\
Zhejiang 1 & - & 9.20 & 0.07 & 52.90 & 17.60 & 0.09 & 24.60 & 23.70 & 70.60 \\
China 2 & - & 11.20 & 0.10 & 61.00 & 22.60 & 0.07 & 26.90 & 26.00 & 72.40 \\
RSV3 & - & 30.00 & 0.30 & 150.00 & 50.00 & 0.50 & 60.00 & 70.00 & 200.00 \\
\hline
\end{tabular}

Note: S.D, standard deviation; CV, coefficient of variation; 1 Background value of Zhejiang Province [42]; 2 Background value of China (China National Environmental Monitoring Center, 1990); RSV, risk-screening values for soil contamination of agricultural land at $\mathrm{Ph}<5.5$ (GB 15618-2018); “-" no data.

Compared with agricultural soils in the other regions of the Yangtze River Delta [27-31], the overall concentrations of HMs in the study area are lower (Figure 2). It is shown that it pollutes the soil environment lightly in the process of economic development in the region. Among them, $\mathrm{Cr}, \mathrm{Cu}, \mathrm{Ni}$, and $\mathrm{Zn}$ have the lowest concentration in the whole delta region. Although the $\mathrm{Cd}$ concentration in the study area is lower than that in other cities in Zhejiang Province, it is significantly higher than that in the cities in Jiangsu and Anhui. The $\mathrm{Pb}$ concentration is higher than Hangzhou, Ningbo, Suzhou, and Yangzhou, while it is much lower than Shanghai and Nanjing. Therefore, it is worth mentioning that the economic development of the study area belongs to the upper-middle level in this area, but the degree of pollution is relatively low, indicating that the soil environmental planning and governance in this area can provide some reference for other areas.

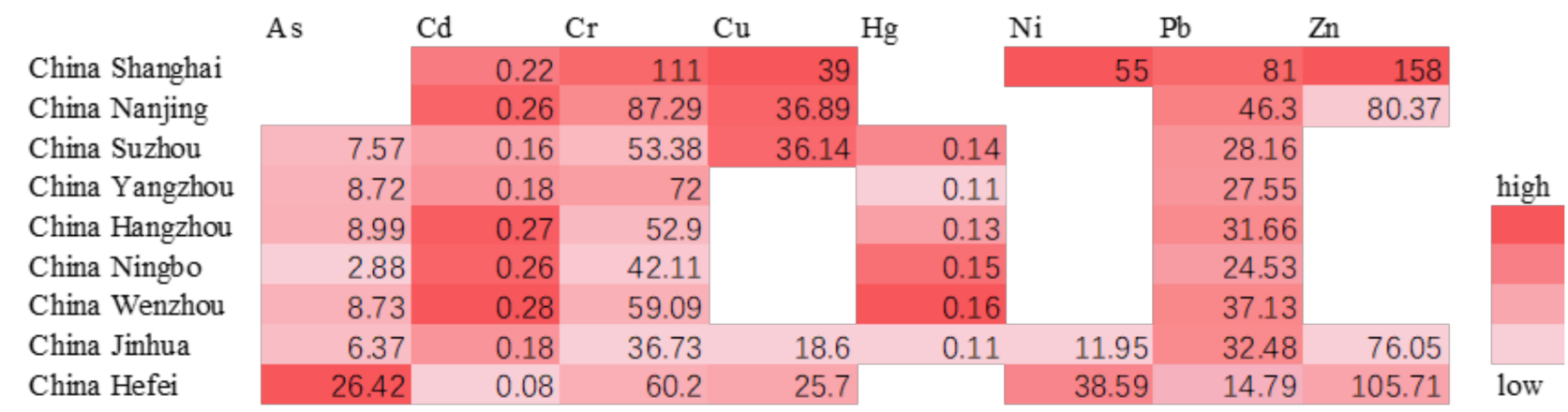

Figure 2. Contrast of soil heavy metal concentrations $\left(\mathrm{mg} \mathrm{kg}^{-1}\right)$ of agricultural land in the Yangtze River Delta of China. 


\subsection{Spatial Distribution of Heavy Metals in Soil}

Figure 3 shows the spatial distribution of HMs concentration in agricultural soils in Jinhua City. The high concentration areas of As is mainly concentrated in the central, northern and western parts of Jinhua City, including the center of Lanxi, Jindong, and Yiwu, eastern Pujiang, and northwestern Wucheng. Generally, As is closely related to industrial emissions $[26,43,44]$. Many factories were built near the river to facilitate the sewage treatment of factories and enterprises. As may be related to industrial activities such as industrial discharge and sewage sludge in this area, so it can be found that As elements are mainly distributed along the river $[45,46]$. Similarly, the spatial distribution of $\mathrm{Hg}$ is relatively uniform, with sporadic high concentration areas along with the Wujiang River. Studies have shown that coal-burning activities are prone to producing a large amount of $\mathrm{Hg}$, and $\mathrm{Hg}$ has the characteristics of volatility and high fluidity, making it easy for it to enter the atmosphere for migration and diffusion [15,47]. The flow of $\mathrm{Hg}$ in the atmosphere is less obstructed, and it only enters the soil under weather such as rainfall and has little impact on the soil within a certain range, so the spatial distribution of $\mathrm{Hg}$ brought by atmospheric deposition is more uniform [48]. In addition, similar to the distribution of As element, most of the factories in the study area are located close to the river, and the exhaust gas also causes the accumulation of $\mathrm{Hg}$ in the area [15]. The highest concentrations of $\mathrm{Cr}, \mathrm{Cu}$, and $\mathrm{Ni}$ are concentrated in the central and western parts of Jinhua City, including Lanxi, Wucheng, and Jindong. Alongside this, the highest concentrations of $\mathrm{Pb}$ and $\mathrm{Cd}$ are mainly centered in Wucheng and the junction of Lanxi-Wucheng, respectively (which is the downtown of Jinhua and contains large-scale development zones such as Jinhua Technology and Economic Development Zone, Jinxi Development Zone, etc.). A previous study has demonstrated that the unreasonable discharge of domestic tannery and electroplating enterprises may cause $\mathrm{Cr}$ pollution [49], and the discharge of waste liquid from chemical plants usually causes the accumulation of $\mathrm{Cu}$ [26,42], which may be one of the reasons for the accumulation of $\mathrm{Cr}$ and $\mathrm{Cu}$ in this area. Along with this, the $\mathrm{Pb}$ and $\mathrm{Cd}$ used in dyes of textile printing and dyeing enterprises will eventually enter the soil through sewage treatment [50]. Simultaneously, the agricultural land in this area is widely distributed, and unreasonable agricultural activities, such as excessive use of fertilization, pesticides and herbicides, and sewage irrigation may also lead to the accumulation of $\mathrm{Cd}$ and $\mathrm{Cu}$ in the soil [51]. Unlike other $\mathrm{HMs}$, the high concentration areas of $\mathrm{Zn}$ are mainly distributed in Wuyi. Moreover, $\mathrm{Ni}, \mathrm{Cu}$, and $\mathrm{Zn}$ are also significantly enriched in the southern part of Wuyi. According to field investigations, Wuyi has large factories and enterprises such as the Hardware Industrial Zone and Huashan Industrial Park, which will inevitably emit a lot of smoke and dust during the production process. Additionally, Wuyi is a well-known fluorite mining base in China, and the industrial sites, transportation roads, and underground mining areas will all have an impact on the surrounding ecological environment, especially the groundwater and soil environment [11]. Firstly, the HMs contained in the waste slag and dust will migrate to the soil surface under the rain leaching of the waste ore [23]; secondly, the waste gas and dust generated in the transportation process of vehicles will inevitably produce the accumulation of zinc and other elements in the surrounding agricultural soil [52]. Soil pH ranges between 4.65-6.46 in the study area (Figure 3i) and the soil pH in Jindong District is weakly acidic, while the soil $\mathrm{pH}$ in the southwest of the study area (mainly including Wucheng, Wuyi, and Yongkang) is strongly acidic. 

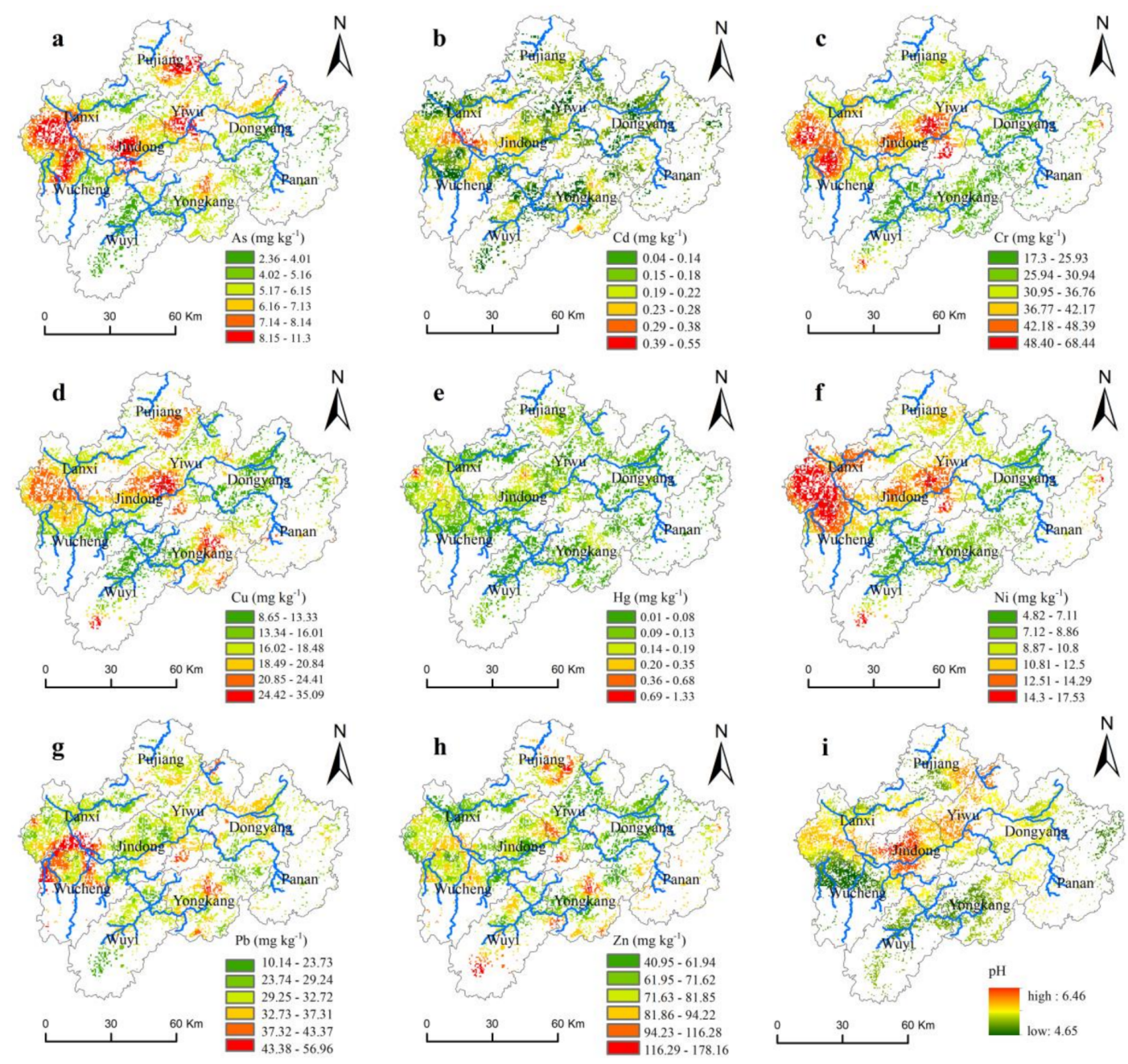

Figure 3. Spatial distribution of soil heavy metals ((a): As, (b): $\mathrm{Cd},(\mathbf{c}): \mathrm{Cr},(\mathbf{d}): \mathrm{Cu},(\mathbf{e}): \mathrm{Hg}$, (f): $\mathrm{Ni},(\mathbf{g}): \mathrm{Pb},(\mathbf{h}): \mathrm{Zn},(\mathbf{i}): \mathrm{pH})$ concentration in the agricultural land of Jinhua City.

\subsection{Sources Apportionment of Heavy Metals in Soil \\ 3.3.1. Source Apportionment of APCS-MLR and PMF}

The principal component analysis method was used to further analyze the possible sources of HM pollutants in the soil of Jinhua City. First, the principal component analysis of the concentration of eight HMs in the soil was performed, four principal components were identified, and the corresponding cumulative contribution rate of the four principal components was $82.16 \%$ (Table S3). However, there is a lack of information in the method of principal component analysis. Thus, we introduced a zero-concentration variable to calculate the absolute principal component (Table 2). Then, by taking the factor scores after the absolute principal component as the independent variable, taking the standardized pollutant concentration as the dependent variable, and substituting it into the multiple linear regression program, the calculated contribution rates of the four main pollution sources are $43.1 \%, 27.8 \%, 15.4 \%$, and $13.7 \%$.

The loadings of the four factors of principal component were listed in Table 1. The variance contribution rate of APCS-MLR_1 is $35.42 \%$. Cr, Ni, and $\mathrm{Cu}$ have larger loads on factor 1 , and their contribution rates are $89.2 \%, 86.0 \%$, and $83.4 \%$, respectively. Compared with the descriptive statistical results (Table 1), the contents of these elements are lower than or close to the background value (especially for $\mathrm{Cr}$ and $\mathrm{Ni}$, whose contents do not exceed the soil background value of Zhejiang Province and are less affected by human activities). Simultaneously, earlier studies found that these elements are mainly controlled by the geological background $[23,48]$. In addition, the PMF_1 is consistent with the results 
obtained by APCS-MLR_1. It also has a higher contribution rate to $\mathrm{Ni}, \mathrm{Cr}$, and $\mathrm{Cu}$, which are $70.7 \%, 66.9 \%$, and $40.0 \%$, respectively. Therefore, the APCS-MLR_1 and PMF_F1 can be regarded as a "natural sources factor".

Table 2. Varimax rotated matrix for the parameters in the first four principal components obtained via APCS analysis.

\begin{tabular}{ccccc}
\hline \multirow{2}{*}{ Elements } & \multicolumn{4}{c}{ Component } \\
\cline { 2 - 4 } & Factor 1 & Factor 2 & Factor 3 & Factor 4 \\
\hline $\mathrm{As}$ & 0.298 & 0.014 & 0.812 & -0.464 \\
$\mathrm{Hg}$ & 0.104 & 0.404 & 0.443 & 0.787 \\
$\mathrm{Cr}$ & 0.892 & -0.285 & 0.056 & 0.018 \\
$\mathrm{Ni}$ & 0.860 & -0.298 & -0.033 & 0.077 \\
$\mathrm{Cu}$ & 0.834 & -0.088 & -0.057 & 0.084 \\
$\mathrm{Zn}$ & 0.644 & 0.395 & -0.384 & -0.075 \\
$\mathrm{~Pb}$ & 0.068 & 0.846 & 0.002 & -0.176 \\
$\mathrm{Cd}$ & 0.289 & 0.783 & -0.049 & -0.125 \\
\hline
\end{tabular}

The variance contribution rate of APCS-MLR_2 is $22.82 \%$. Pb and Cd have larger loads on APCS-MLR_2, with contributions of $84.6 \%$ and $78.3 \%$, respectively, which were higher than the corresponding background values of Zhejiang Province, and affected by human factors. An earlier study has shown that soil $\mathrm{pH}$ has an important effect on the migration and transformation of Cd elements in the soil. Usually, the solubility of Cd decreases with the increases of $\mathrm{pH}$ value, which makes it difficult for the $\mathrm{Cd}$ in the soil to migrate and deposit in situ [10]. Figure 3 also shows that the distribution of high concentration area of $\mathrm{Cd}$ basically consistent with the high value area of soil $\mathrm{pH}$. The use of fertilizers, herbicides, pesticides, and the discharge of wastewater from factories and enterprises are important ways to artificially change the $\mathrm{pH}$ value of the soil environment, which in turn affects the migration and accumulation of corresponding soil heavy metals in the soil. Therefore, $\mathrm{Cd}$ is indicated to mainly come from the application of the chemical fertilizers. Although the application of chemical fertilizers can effectively supplement the nutrients required for crop growth and improve the quality and yield of food, excessive input will cause the accumulation of $\mathrm{Cd}$ in the soil [11]. Besides, Cd may also come from the "three wastes" emissions from electroplating and metallurgy industries [51]. It has been demonstrated that $\mathrm{Pb}$ mainly comes from automobile exhaust and coal combustion [24]. Therefore, the APCS-MLR_2 can be regarded as a "mixed pollution sources of industrial, agriculture, and transportation".

The PMF_2 has a higher contribution rate to Cd (69.7\%) and Cu (53.0\%), and the mean concentration of $\mathrm{Cd}$ and $\mathrm{Cu}$ are higher than the corresponding background values of Zhejiang Province and their CV revealed a moderate variability, indicating that they are affected by human factors. Previous studies have shown that chemical fertilizers, pesticides, and plastic films used for crop insulation in agricultural production are important reasons for the accumulation of $\mathrm{Cu}$ and $\mathrm{Cd}$ in agricultural soil [48,52]. It has been proven that the application of nitrogen and phosphate fertilizers may cause the accumulation of $\mathrm{Cd}$ in agricultural soil [51]. Most pesticides contain large amounts of HMs. For example, herbicides and pesticides contain a large amount of $\mathrm{Cu}$ [5]. Moreover, the excrement of livestock and poultry are also the important sources of HMs in agricultural soil [21]. Cu and other elements are usually added as additives to the feed for raising livestock and eventually penetrate into the soil through the residual infiltration of the food chain and cause soil pollution [3]. Therefore, PMF_2 can be regarded as the "agricultural sources factor".

The variance contribution rate of APCS-MLR_3 is $12.67 \%$, with the highest contribution to As $(81.2 \%)$, and its mean concentration is higher than the background value of Zhejiang Province. Earlier studies have proven that As mainly comes from industrial pollution emissions [26,42]. There are 3586 industrial enterprises in the study area, and As is closely related to industrial activities. PMF_3 also has a high contribution rate to As, 
and its contribution rate is $68.7 \%$. Thus, here the same explanation applies. Therefore, the PCAS-MLR_3 and PMF_3 can be characterized as the "industrial source factor".

The variance contribution rate of APCS_4 is $11.25 \%$, and has the higher contribution rate to $\mathrm{Hg}(78.7 \%)$. Previous studies have shown that the burning of fossil fuels such as coal will release a large amount of $\mathrm{Hg}[15,47]$. According to the environmental survey of the study area, there are many coal-fired powers plants and other industrial areas in the study area. During the coal-burning operation of these factories, a large amount of $\mathrm{Hg}$ will inevitably be released into the atmosphere and finally sink into the soil under the weather such as rainfall [47]. The result of PMF_4 is consistent with the result of APCS-MLR_4, The contribution rate is $84.2 \%$. Therefore, all fourth factors can be represented as the "atmospheric deposition sources factor".

The PMF_5 has a higher contribution rate to $\mathrm{Pb}(74.9 \%)$ and $\mathrm{Zn}(63.1 \%)$. Studies have shown that $\mathrm{Pb}$ and $\mathrm{Zn}$ pollution are closely related to traffic [53]. In order to improve the antiknock performance of gasoline, "lead water" (tetraethyl lead) is usually added to gasoline and the leaded exhaust pollutants emitted by vehicles will eventually enter the soil [14]. $\mathrm{Zn}$ is an important part of antioxidants in automobile tires [53]. Dust generated by the wear and tear of automobile tires will also fall into the surface soil, making Zn enter the soil [4]. The closer it is to the road, the higher corresponding HM accumulation. The highway passenger traffic volume of Jinhua City is 107.73 million people, ranking second in Zhejiang Province, and the freight volume is 99.11 million tons. The huge traffic volume inevitably releases a large amount of HMs. Therefore, it can be concluded that PMF_5 can represent the traffic pollution sources factor.

\subsubsection{Comparison of APCS-MLR and PMF}

Compared with PMF model, the number of sources identified by the APCS-MLR is reduced (Table 3). In addition, APCS-MLR does not have a good analysis of the source of APCS-MLR_2, which contains mixed sources of agriculture, transportation, etc. This might be attribute to the APCS-MLR excludes some variables with poor publicity in the calculation process [22]. There are also certain differences in the contribution rate between two models. For example, in terms of natural sources, the contribution rate obtained by APCS-MLR is $43.1 \%$, while the contribution rate obtained by PMF model analysis is $24.29 \%$. The reason for the difference in the contribution rate between APCS-MLR and PMF model is that the principal component does not consider the uncertainty of the data in the calculation process, and there is a small amount of information loss [54]. In the PMF model, the uncertainty data of soil HMs and non-negative constraints were added in the calculation process, which made the result more reasonable [54]. Therefore, PMF can provide a better result than APCS-MLR.

Some previous studies have shown that the sources apportioned by the PMF model are more reliable than those apportioned by the APCS-MLR [55-57], while others are not. The results of this study show that APCS-MLR cannot accurately identify some similar sources. For example, the pollution source 2 resolved by APCS-MLR is a mixed source, while the PMF model can identify more pollution sources. Therefore, it may be concluded that the PMF model has better explanatory power for areas with few pollution sources and light pollution and has stronger credibility for areas with more complicated pollution, which is basically consistent with the research of $\mathrm{Wu}$ et al. [58]. Overall, in the specific soil pollution investigation, appropriate receptor models were chosen based on the size of the research area and the soil pollution situation. For example, the PMF model was more suitable in a large-scale urban soil pollution source survey, while APCS-MLR model was more suitable for a small-scale survey of pollution sources such as factories and enterprises.

We evaluated the suitability of each soil HM with the model by comparing the measured concentration with the predicted concentration, as well as the coefficient of determination $\left(R^{2}\right)$ and prediction error [18]. Overall, both models show a higher fitting ability, and that of the PMF is higher than that of APCS-MLR (Table 4). The $R^{2}$ of HMs in APCS-MLR are all greater than 0.71 , and the $R^{2}$ of PMF model are greater than 0.81 . The prediction 
errors of the two models are less than 1, except for Pb in APCS-MLR model. For the APCSMLR model, all elements are overestimated. In comparison, the PMF model overestimates the $\mathrm{As}, \mathrm{Cd}$, and $\mathrm{Ni}$, and underestimates the $\mathrm{Cr}, \mathrm{Cu}$, and $\mathrm{Pb}$.

Table 3. Comparison results of APCS-MLR and PMF sources analysis.

\begin{tabular}{ccccccc}
\hline Models & Source 1 & Source 2 & Source 3 & Source 4 & Source 5 & $\begin{array}{c}\text { Cumulative } \\
\text { Contribution }\end{array}$ \\
\hline \multirow{2}{*}{ APCS-MLR } & Natural sources & Mixed sources & $\begin{array}{c}\text { Industrial } \\
\text { sources }\end{array}$ & $\begin{array}{c}\text { Atmospheric } \\
\text { deposition sources }\end{array}$ & - & \\
& $43.1 \%$ & $27.8 \%$ & $15.4 \%$ & $13.7 \%$ & $100 \%$ \\
\hline \multirow{2}{*}{ PMF } & Natural sources & Agricultural & Industrial & Atmospheric & Traffic sources \\
& $24.29 \%$ & sources & sources & deposition sources & $18.9 \%$ & $100 \%$ \\
\hline
\end{tabular}

Table 4. Relationship of soil heavy metal concentrations quantified by instrument and predicted by the APCS-MLR and PMF models.

\begin{tabular}{|c|c|c|c|c|c|c|c|}
\hline \multirow[b]{2}{*}{ Elements } & \multirow{2}{*}{$\begin{array}{l}\text { Measured Value } \\
\quad\left(\mathrm{mg} \mathrm{kg}^{-1}\right)\end{array}$} & \multicolumn{3}{|c|}{ APCS-MLR } & \multicolumn{3}{|c|}{ PMF } \\
\hline & & $\mathbf{R}^{2}$ & $\begin{array}{l}\text { Predicted Value } \\
\quad\left(\mathrm{mg} \mathrm{kg}^{-1}\right)\end{array}$ & Error (\%) & $\mathbf{R}^{2}$ & $\begin{array}{l}\text { Predicted Value } \\
\quad\left(\mathrm{mg} \mathrm{kg}^{-1}\right)\end{array}$ & Error (\%) \\
\hline As & 6.37 & 0.96 & 6.42 & 0.70 & 0.99 & 6.37 & 0.04 \\
\hline $\mathrm{Cd}$ & 0.18 & 0.72 & 0.18 & 0.05 & 0.81 & 0.18 & 0.01 \\
\hline $\mathrm{Cr}$ & 36.73 & 0.88 & 36.73 & 0.23 & 0.95 & 35.63 & -0.64 \\
\hline $\mathrm{Cu}$ & 18.60 & 0.71 & 18.9 & 0.65 & 0.84 & 17.29 & -0.72 \\
\hline $\mathrm{Hg}$ & 0.11 & 0.99 & 0.11 & 0.17 & 0.99 & 0.11 & 0.00 \\
\hline $\mathrm{Ni}$ & 11.95 & 0.84 & 12.41 & 0.82 & 0.89 & 11.95 & 0.25 \\
\hline $\mathrm{Pb}$ & 32.48 & 0.75 & 35.62 & 2.1 & 0.83 & 31.97 & -0.93 \\
\hline $\mathrm{Zn}$ & 76.05 & 0.72 & 77.53 & 0.86 & 0.85 & 76.53 & 0.61 \\
\hline
\end{tabular}

In general, the analysis results of the APCS-MLR and PMF models are roughly the same, and both can be applied to the source analysis of soil HMs (Figure 4). However, in terms of the contribution rate of source analysis, the PMF model has greater advantages than APCS-MLR in this study.

(a)APCS-MLR

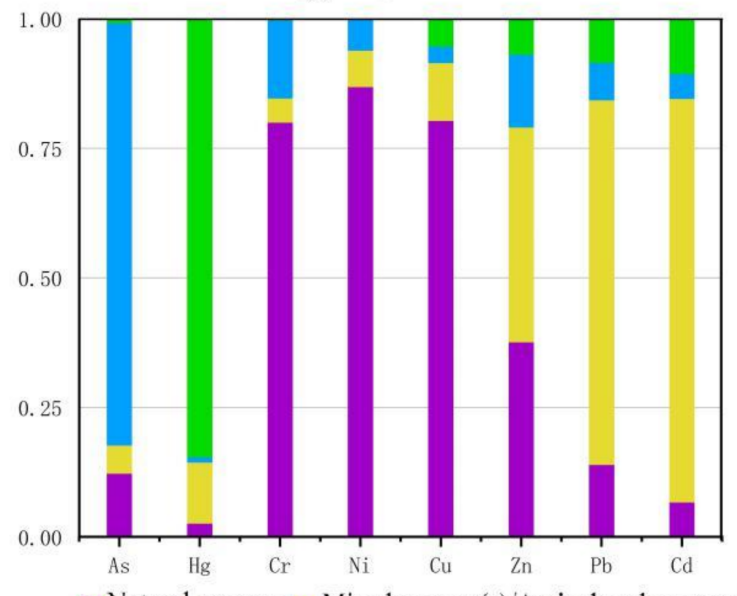

(b)PMF

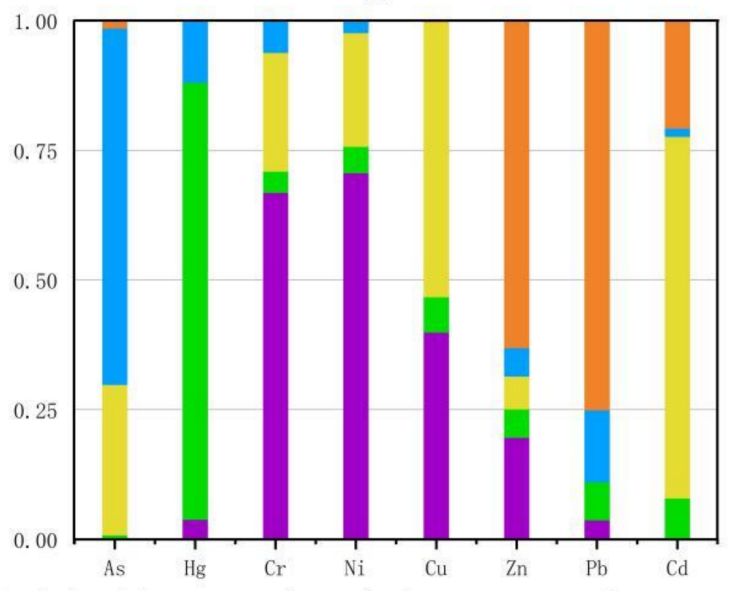

Figure 4. Source contributions to heavy metals derived from APCS-MLR (a) and PMF (b). APCS- MLR, absolute principal component scores-multiple linear regression; $\mathrm{PMF}$, positive matrix factorization. 


\subsection{Health Risk Assessment of Heavy Metals in Soil}

\subsubsection{Carcinogenic and Non-Carcinogenic Risk}

The RI and HI assessment results of adults and children under different exposure routes are shown in Tables S4 and S5. The RI of the three different exposure routes are quite different and followed the rank order: nondietary ingestion $>$ dermal contact $>$ respiratory inhalation. The RI of different HMs are also significantly different, and the levels of RI were ranked as follows: As $>\mathrm{Cd}>\mathrm{Cr}$. Among them, the RI of $\mathrm{Cr}$ element is less than $10^{-6}$, indicating that $\mathrm{Cr}$ will not pose a threat to the health of residents for the time being. The RI of As and $\mathrm{Cd}$ are between $10^{-4}-10^{-6}$, which is within an acceptable range. However, the total RI of multiple HMs to children is $1.30 \times 10^{-4}$, which exceeds the RI threshold, and relevant environmental departments thus need to pay attention. The HI of the three exposure routes in study area are significantly different. Among them, the value of nondietary ingestion is the largest, followed by dermal contact, and then respiratory inhalation as the smallest. The $\mathrm{HI}$ of the $8 \mathrm{HMs}$ followed the rank order: $\mathrm{As}>\mathrm{Cr}>\mathrm{Pb}>\mathrm{Ni}$ $>\mathrm{Cu}>\mathrm{Hg}>\mathrm{Zn}>\mathrm{Cd}$. Among them, the $\mathrm{HI}$ of children is much greater than that of adults, but both are less than 1, indicating that the health risk of HMs in agricultural soil in the study area is within an acceptable range and will not cause $\mathrm{HI}$ to surrounding residents. A comparative analysis of the RI and HI of HMs in agricultural soils in the study area shows that children have a higher health risk than adults and are more susceptible to soil pollution hazards. Combined with previous studies, it can be found that although the health risks of soil HMs varied greatly in different regions, the RI and $\mathrm{HI}$ of children are usually greater than those of adults [59-62]. The main reason is that children's behavior patterns determine that they are more likely to be exposed to the soil environment, especially dermal contact [39], and children are more sensitive to environmental pollution and have lower immunity, which make them more vulnerable to soil pollution hazards [63]. Therefore, it is necessary to instruct children to wash their hands frequently and correctly, maintain hand hygiene, and change laundry frequently [4]. Secondly, it can be seen that whether it is children or adults, the RI and $\mathrm{HI}$ of nondietary ingestion are greater than the two exposure routes of respiratory inhalation and dermal contact, which is basically consistent with the results of previous studies [64,65].

\subsubsection{Health Risk Assessment from Different Sources}

The PMF model was performed to quantify the different HMs sources to RI and HI (Figure 5). It can be found that RI and HI of different HMs sources have the similar trend in the risk probability of adults and children. Industrial sources have the highest $\mathrm{HI}$ to adults $(32.92 \%)$ and children $(30.47 \%)$, followed by agricultural sources $(21.34 \%$ and $29.31 \%$ ), natural sources (26.26\% and $18.56 \%)$, traffic sources $(15.47 \%$ and $17.04 \%)$, and atmospheric deposition sources (4.02\% and $4.62 \%)$. Therefore, the control of $\mathrm{Cd}, \mathrm{Cu}$, and As from industrial and agricultural sources is the key to preventing $\mathrm{HI}$ for adults and children. Regarding the RI, industrial sources (60.74\% and $61.50 \%$ ) and agricultural sources (32.94\% and $33.19 \%$ ) contributed the highest RI to adults and children. It should be pointed out that in this study, industrial sources (13.42\%) accounted for a small proportion of the contribution rate of soil HM pollution sources. However, the health risks caused by it are high whether it is RI or HI. This may be that the main HMs from industrial sources such as have strong toxicity and high slope coefficient [65]. Therefore, we can find that the health risks caused by higher pollution sources are not necessarily high, which is basically consistent with the previous conclusions $[4,24,25]$. Therefore, the control of industrial sources and agricultural sources are the key to prevention for adults and children. 


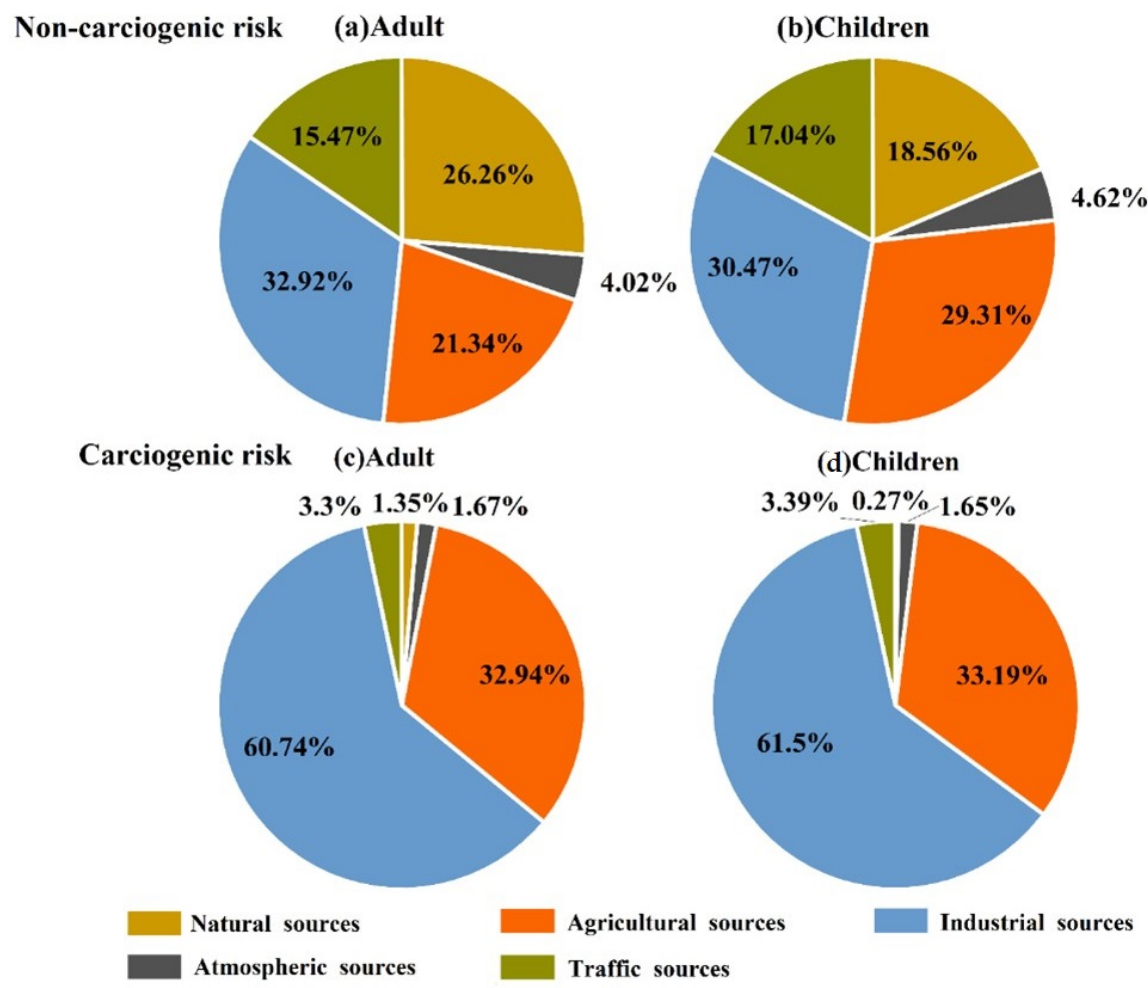

Figure 5. Contribution percentage of noncarcinogenic risks $(\mathbf{a}, \mathbf{b})$ and carcinogenic risks $(\mathbf{c}, \mathbf{d})$ from different sources.

The noncarcinogenic risk values for adults and children based on different pollution sources are less than 1 , indicating that the noncarcinogenic risk caused by each pollution source is basically negligible; the carcinogenic risk for adults varies among different pollution sources, with the carcinogenic risk from natural sources, agricultural sources, atmospheric deposition sources, and traffic sources less than $10^{-6}$, and that of industrial sources between $10^{-6}$ and $10^{-4}\left(1.05 \times 10^{-5}\right)$. There are also large differences in the carcinogenic risks to children from different pollution sources, with natural sources having carcinogenic values less than $10^{-6}$, atmospheric deposition sources and traffic sources having values of $2.14 \times 10^{-5}$ and $4.40 \times 10^{-6}$, respectively, and agricultural and industrial sources having values of $4.31 \times 10^{-5}$ and $7.98 \times 10^{-5}$, respectively. The USEPA guidelines indicate that when $\mathrm{CR}<10^{6}$, the carcinogenic risk is basically negligible; many scholars also consider that when $10^{-6}<\mathrm{CR}<10^{-4}$, the carcinogenic risk is within the acceptable range; when $\mathrm{CR}>10^{-4}$, it indicates that there may be a greater carcinogenic risk [59-62]. In this study, a CR value between $10^{-6}$ and $10^{-5}$ was defined as low risk, a CR value between $10^{-5}$ and $10^{-4}$ was defined as medium risk, and a $C R$ value $>10^{-4}$ was defined as high risk based on the actual local situation. Therefore, the carcinogenic risk to children from industrial and agricultural sources in the study area is medium, and the risk from atmospheric deposition sources and traffic sources is low. However, the carcinogenic risk to adults from industrial sources is low, the risk from agricultural sources is medium, and the carcinogenic risk from other pollution sources is basically negligible (Table 5). The industrial agglomeration in the study area is obvious, and there are many industrial zones, such as apparel factories, rubber factories, and plastic industries. Therefore, the overall cancer risk from industrial sources in the study area is medium to low, but since the spatial distribution of HMs pollution is mostly concentrated in densely populated areas, the subsequent supervision and management of factory enterprises with high pollution and discharge should also be strengthened to reduce the possible health risks caused by soil pollution in the study area. 
Table 5. Health risks to adults and children from different channels based on different sources.

\begin{tabular}{|c|c|c|c|c|c|c|c|}
\hline & & & $\begin{array}{l}\text { Natural } \\
\text { Sources }\end{array}$ & $\begin{array}{l}\text { Agricultural } \\
\text { Sources }\end{array}$ & $\begin{array}{l}\text { Industrial } \\
\text { Sources }\end{array}$ & $\begin{array}{c}\text { Atmospheric } \\
\text { Deposition } \\
\text { Sources }\end{array}$ & $\begin{array}{l}\text { Traffic } \\
\text { Sources }\end{array}$ \\
\hline \multirow{10}{*}{$\begin{array}{l}\text { Noncarcinogenic } \\
\text { risks }\end{array}$} & \multirow{5}{*}{ Adult } & $\mathrm{HI}_{\text {ing }}$ & $4.88 \times 10^{-3}$ & $5.01 \times 10^{-3}$ & $8.81 \times 10^{-3}$ & $9.29 \times 10^{-4}$ & $3.94 \times 10^{-3}$ \\
\hline & & $\mathrm{HI}_{\mathrm{inh}}$ & $6.94 \times 10^{-5}$ & $2.81 \times 10^{-5}$ & $9.57 \times 10^{-6}$ & $5.07 \times 10^{-6}$ & $3.98 \times 10^{-6}$ \\
\hline & & $\mathrm{HI}_{\mathrm{derm}}$ & $2.51 \times 10^{-3}$ & $1.02 \times 10^{-3}$ & $5.20 \times 10^{-4}$ & $2.05 \times 10^{-4}$ & $4.45 \times 10^{-4}$ \\
\hline & & HI & $7.46 \times 10^{-3}$ & $6.06 \times 10^{-3}$ & $9.34 \times 10^{-3}$ & $1.14 \times 10^{-3}$ & $4.39 \times 10^{-3}$ \\
\hline & & Risk level & negligible & negligible & negligible & negligible & negligible \\
\hline & \multirow{5}{*}{ Children } & $\mathrm{HI}_{\text {ing }}$ & $9.56 \times 10^{-3}$ & $1.64 \times 10^{-2}$ & $1.74 \times 10^{-2}$ & $2.57 \times 10^{-3}$ & $9.64 \times 10^{-3}$ \\
\hline & & $\mathrm{HI}_{\mathrm{inh}}$ & $2.59 \times 10^{-5}$ & $1.14 \times 10^{-5}$ & $3.60 \times 10^{-6}$ & $1.99 \times 10^{-6}$ & $1.75 \times 10^{-6}$ \\
\hline & & $\mathrm{HI}_{\text {derm }}$ & $1.20 \times 10^{-3}$ & $6.37 \times 10^{-4}$ & $2.53 \times 10^{-4}$ & $1.15 \times 10^{-4}$ & $2.58 \times 10^{-4}$ \\
\hline & & $\mathrm{HI}$ & $1.08 \times 10^{-3}$ & $1.70 \times 10^{-2}$ & $1.77 \times 10^{-2}$ & $2.69 \times 10^{-3}$ & $9.90 \times 10^{-3}$ \\
\hline & & Risk level & negligible & negligible & negligible & negligible & negligible \\
\hline \multirow{10}{*}{ Carcinogenic risks } & \multirow{5}{*}{ Adult } & $\mathrm{RI}_{\text {ing }}$ & 0 & $5.48 \times 10^{-6}$ & $1.02 \times 10^{-5}$ & $2.70 \times 10^{-7}$ & $5.61 \times 10^{-7}$ \\
\hline & & $\mathrm{RI}_{\mathrm{inh}}$ & $2.34 \times 10^{-7}$ & $8.65 \times 10^{-8}$ & $3.63 \times 10^{-8}$ & $1.45 \times 10^{-8}$ & $3.05 \times 10^{-10}$ \\
\hline & & $\mathrm{RI}_{\text {derm }}$ & 0 & $1.33 \times 10^{-7}$ & $2.83 \times 10^{-7}$ & $5.26 \times 10^{-9}$ & $9.79 \times 10^{-9}$ \\
\hline & & $\mathrm{HI}$ & $2.34 \times 10^{-7}$ & $5.70 \times 10^{-6}$ & $1.05 \times 10^{-5}$ & $2.90 \times 10^{-7}$ & $5.71 \times 10^{-7}$ \\
\hline & & Risk level & negligible & Low & Medium & negligible & negligible \\
\hline & \multirow{5}{*}{ Children } & $\mathrm{RI}_{\text {ing }}$ & 0 & $4.27 \times 10^{-5}$ & $7.92 \times 10^{-5}$ & $2.11 \times 10^{-6}$ & $4.38 \times 10^{-6}$ \\
\hline & & $\mathrm{RI}_{\mathrm{inh}}$ & $3.50 \times 10^{-7}$ & $1.29 \times 10^{-7}$ & $5.43 \times 10^{-8}$ & $2.17 \times 10^{-8}$ & $4.56 \times 10^{-10}$ \\
\hline & & $\mathrm{RI}_{\text {derm }}$ & 0 & $2.55 \times 10^{-7}$ & $5.42 \times 10^{-7}$ & $1.01 \times 10^{-8}$ & $1.88 \times 10^{-8}$ \\
\hline & & HI & $3.50 \times 10^{-7}$ & $4.31 \times 10^{-5}$ & $7.98 \times 10^{-5}$ & $2.14 \times 10^{-6}$ & $4.40 \times 10^{-6}$ \\
\hline & & Risk level & negligible & Medium & Medium & Low & Low \\
\hline
\end{tabular}

\section{Conclusions}

This study demonstrates the spatial variability, potential sources of HMs in agricultural soils of subtropical China. Then, an integrated approach combining human health risk assessment model with PMF model was proposed to quantitative human health risks from identified sources of soil HMs and determine priority control sources in this study. The mean concentrations of $\mathrm{Cd}, \mathrm{Cu}, \mathrm{Hg}, \mathrm{Pb}$, and $\mathrm{Zn}$ in the soil were higher than the corresponding background values in Zhejiang Province, while the mean concentrations of determined 8 HMs were less than their corresponding risk-screening values for soil contamination of agricultural land. The high concentration of As and $\mathrm{Hg}$ are roughly distributed along the Wujiang River, while the $\mathrm{Cu}, \mathrm{Ni}, \mathrm{Cd}$, and $\mathrm{Pb}$ accumulated in large patches in the central and western parts of the Jinhua City. Besides, $\mathrm{Cr}, \mathrm{Ni}, \mathrm{Cu}$, and $\mathrm{Zn}$ are also accumulated in the southern of Wuyi County. PMF model performed better than APCS-MLR model in the identification of major sources of soil HMs as it revealed higher $\mathrm{R}^{2}$ value (0.81-0.99) and lower prediction error $(-0.93-0.25 \%)$. PMF model also had higher accuracy than APCS-MLR model in the estimation of source contribution, and apportioned five sources, namely, agricultural sources (30.06\%), natural sources $(24.29 \%)$, traffic sources $(18.9 \%)$, industrial sources $(13.42 \%)$, and atmospheric deposition sources $(13.27 \%)$, respectively. Both RI and HI of adults are below the safety threshold, while the RI of children has exceeded the safety threshold, indicating that local children are already facing the threat of RI, and needs to be concerned by relevant departments. Moreover, a PMF based human health risk assessment model indicated that industrial sources contributed the highest risk to $\mathrm{HI}(32.92 \%$ and $30.47 \%)$ and RI $(60.74 \%$ and $61.50 \%)$ for adults and children, followed by agricultural sources $(21.34 \%, 29.31 \%$ and $32.94 \%, 33.19 \%)$. Therefore, integrated environmental management should be implemented to control and reduce the accumulation of soil HMs from these two sources. This study provided an effective approach to quantify the priority pollution sources of concern for human health risk, which is of great significance for pollution control and risk reduction under limited resources. 
Supplementary Materials: The following are available online at https:/ /www.mdpi.com/article/ 10.3390/land10101016/s1, Figure S1: land use map of the study area, Table S1: values of exposure parameters of the health risk assessment model, Table S2: reference doses and carcinogenic heavy metal slope factors for different exposure routes, Table S3: the eigenvalues of principal component analysis and their contribution rate, Table S4: different exposure routes and total carcinogenic health risk assessment results in the study area, Table S5: different exposure routes and total noncarcinogenic health risk assessment results in the study area.

Author Contributions: P.L.: Data curation, Methodology, Writing-original draft; T.W.: Conceptualization, Writing-original draft. G.J.: Software, Visualization. L.P.: Funding acquisition, Resources. Y.L.: Methodology, Supervision. J.Z.: Visualization, Supervision. F.X.: Investigation, Writing-review \& editing. X.X.: Conceptualization, Writing-review \& editing. All authors have read and agreed to the published version of the manuscript.

Funding: This study was financially supported by the National Natural Science Foundation of China $(42101068,41871083,42171245,41701618)$, the Science and Technology Planning Project of Jinhua City (2020-4-183, 2021-4-339), and the Natural Science Foundation of Zhejiang Province, China (LQ21D010007, LY21D010008).

Institutional Review Board Statement: Not applicable.

Informed Consent Statement: Not applicable.

Data Availability Statement: The data presented in this paper are available on request from the corresponding author.

Conflicts of Interest: The authors declare no conflict of interest.

\section{References}

1. Han, L.; Chen, R.; Liu, Z.; Chang, S.; Zhao, Y.; Li, L.; Li, R.; Xia, L. Sources of and control measures for PTE pollution in soil at the urban fringe in Weinan, China. Land 2021, 10, 762. [CrossRef]

2. Xie, M.; Li, H.; Zhu, Y.; Xue, J.; You, Q.; Jin, B.; Shi, Z. Predicting bioaccumulation of potentially toxic element in soil-rice systems using multi-source data and machine learning methods: A case study of an industrial city in southeast China. Land 2021, 10, 558. [CrossRef]

3. Belon, E.; Boisson, M.; Deportes, I.Z.; Eglin, T.K.; Feix, I.; Bispo, A.O.; Galsomies, L.; Leblond, S.; Guellier, C.R. An inventory of trace elements inputs to French agricultural soils. Sci. Total Environ. 2012, 439, 87-95. [CrossRef]

4. Wang, F.F.; Guan, Q.Y.; Tian, J.; Lin, J.K.; Yang, Y.Y.; Yang, L.Q.; Pan, N.H. Contamination characteristics, source apportionment, and health risk assessment of heavy metals in agricultural soil in the Hexi Corridor. Catena 2020, 191, 104573. [CrossRef]

5. Wu, J.; Li, J.; Teng, Y.G.; Chen, H.Y.; Wang, Y.Y. A partition computing-based positive matrix factorization (PC-PMF) approach for the source apportionment of agricultural soil heavy metal contents and associated health risks. J. Hazard. Mater. 2020, $388,121766$. [CrossRef] [PubMed]

6. Guo, W.; Wu, T.; Jiang, G.; Pu, L.; Zhang, J.; Xu, F.; Yu, H.; Xie, X. Spatial distribution, environmental risk and safe utilization zoning of soil heavy metals in farmland, subtropical China. Land 2021, 10, 569. [CrossRef]

7. Zheng, H.J.; Liu, Z.; Nie, X.F.; Zuo, J.C.; Wang, L.Y. Comparison of active nitrogen loss in four pathways on a sloped peanut field with red soil in China under conventional fertilization conditions. Sustainability 2019, 11, 6219. [CrossRef]

8. Xie, X.F.; Pu, L.J.; Zhu, M.; Meadows, M.; Sun, L.C.; Wu, T.; Bu, X.G.; Xu, Y. Differential effects of various reclamation treatments on soil characteristics: An experimental study of newly reclaimed tidal mudflats on the east China coast. Sci. Total Environ. 2021, 768, 144996. [CrossRef] [PubMed]

9. Zhao, K.L.; Liu, X.M.; Xu, J.M.; Selim, H.M. Heavy metal contaminations in a soil-rice system: Identification of spatial dependence in relation to soil properties of paddy fields. J. Hazard. Mater. 2010, 181, 778-787. [CrossRef] [PubMed]

10. Zeng, F.R.; Ali, S.; Zhang, H.T.; Ouyang, Y.N.; Qiu, B.Y.; Wu, F.B.; Zhang, G.P. The influence of pH and organic matter content in paddy soil on heavy metal availability and their uptake by rice plants. Environ. Pollut. 2011, 159, 84-91. [CrossRef]

11. Cai, L.M.; Xu, Z.C.; Ren, M.Z.; Guo, Q.W.; Hu, X.B.; Hu, G.C.; Wan, H.F.; Peng, P.G. Source identification of eight hazardous heavy metals in agricultural soils of Huizhou, Guangdong Province, China. Ecotoxicol. Environ. Saf. 2012, 78, 2-8. [CrossRef]

12. Deng, M.; Zhu, Y.; Shao, K.; Zhang, Q.; Shen, J. Metals source apportionment in farmland soil and the prediction of metal transfer in the soil-rice-human chain. J. Environ. Manag. 2020, 260, 110092. [CrossRef] [PubMed]

13. Li, Y.F.; Zhao, Z.Q.; Yuan, Y.; Zhu, P.T.; Li, X.Z.; Guo, A.N.; Yang, Q. Application of modified receptor model for soil heavy metal sources apportionment: A case study of an industrial city, China. Environ. Sci. Pollut. Res. 2019, 26, 16345-16354. [CrossRef] [PubMed]

14. Rodriguez-Seijo, A.; Arenas-Lago, D.; Andrade, M.L.; Vega, F.A. Identifying sources of Pb pollution in urban soils by means of MC-ICP-MS and TOF-SIMS. Environ. Sci. Pollut. Res. 2015, 22, 7859-7872. [CrossRef] 
15. Mamut, A.; Eziz, M.; Mohammad, A.; Anayit, M. The spatial distribution, contamination, and ecological risk assessment of heavy metals of farmland soils in Karashahar-Baghrash oasis, northwest China. Hum. Ecol. Risk Assess. 2017, 23, 1300-1314. [CrossRef]

16. Cai, L.M.; Wang, Q.S.; Wen, H.H.; Luo, J.; Wang, S. Heavy metals in agricultural soils from a typical township in Guangdong Province, China: Occurrences and spatial distribution. Ecotoxicol. Environ. Saf. 2019, 168, 184-191. [CrossRef]

17. Guan, Q.; Zhao, R.; Pan, N.; Wang, F.; Yang, Y.; Luo, H. Source apportionment of heavy metals in farmland soil of Wuwei, China: Comparison of three receptor models. J. Clean. Prod. 2019, 237, 117792. [CrossRef]

18. Chen, H.Y.; Teng, Y.G.; Chen, R.H.; Li, J.; Wang, J.S. Contamination characteristics and source apportionment of trace metals in soils around Miyun Reservoir. Environ. Sci. Pollut. Res. 2016, 23, 15331-15342. [CrossRef]

19. Huston, R.; Chan, Y.C.; Chapman, H.; Gardner, T.; Shaw, G. Source apportionment of heavy metals and ionic contaminants in rainwater tanks in a subtropical urban area in Australia. Water Res. 2012, 46, 1121-1132. [CrossRef]

20. Duan, Y.X.; Zhang, Y.M.; Li, S.; Fang, Q.L.; Miao, F.F.; Lin, Q.G. An integrated method of health risk assessment based on spatial interpolation and source apportionment. J. Clean. Prod. 2020, 276, 123218. [CrossRef]

21. Zhang, M.; Wang, X.P.; Liu, C.; Lu, J.Y.; Qin, Y.H.; Mo, Y.K.; Xiao, P.J.; Liu, Y. Identification of the heavy metal pollution sources in the rhizosphere soil of farmland irrigated by the Yellow River using PMF analysis combined with multiple analysis methods-using Zhongwei City, Ningxia, as an example. Environ. Sci. Pollut. Res. 2020, 27, 16203-16214. [CrossRef] [PubMed]

22. Jia, Z.Y.; Wang, J.X.; Zhou, X.D.; Zhou, Y.J.; Li, Y.; Li, B.J.; Zhou, S.L. Identification of the sources and influencing factors of potentially toxic elements accumulation in the soil from a typical karst region in Guangxi, southwest China. Environ. Pollut. 2020, 256, 113505. [CrossRef] [PubMed]

23. Ma, W.C.; Tai, L.Y.; Qiao, Z.; Zhong, L.; Wang, Z.; Fu, K.X.; Chen, G.Y. Contamination source apportionment and health risk assessment of heavy metals in soil around municipal solid waste incinerator: A case study in North China. Sci. Total Environ. 2018, 631-632, 348-357. [CrossRef] [PubMed]

24. Chen, H.Y.; Teng, Y.G.; Lu, S.J.; Wang, Y.Y.; Wu, J.; Wang, J.S. Source apportionment and health risk assessment of trace metals in surface soils of Beijing metropolitan, China. Chemosphere 2016, 144, 1002-1011. [CrossRef]

25. Liu, J.; Liu, Y.J.; Liu, Y.; Liu, Z.; Zhang, A.N. Quantitative contributions of the major sources of heavy metals in soils to ecosystem and human health risks: A case study of Yulin, China. Ecotoxicol. Environ. Saf. 2018, 164, 261-269. [CrossRef]

26. Zhao, L.S.; Yan, Y.; Yu, R.L.; Hu, G.R.; Cheng, Y.F.; Huang, H.B. Source apportionment and health risks of the bioavailable and residual fractions of heavy metals in the park soils in a coastal city of China using a receptor model combined with $\mathrm{Pb}$ isotopes. Catena 2020, 194, 104736. [CrossRef]

27. Chen, J.L.; Li, R.Y.; Xie, X.J.; Wang, H.; Xu, J.; Shao, J.; Jian, J.; Wuerman, A.; Shen, J.; Yang, Z. Distribution Characteristics and Pollution Evaluation of Heavy Metals in Greenbelt Soils of Nanjing City. Environ. Sci. 2021, 42, 909-916.

28. Fei, X.F.; Lou, Z.H.; Christakos, G.; Ren, Z.Q.; Liu, Q.M.; Lv, X.N. The association between heavy metal soil pollution and stomach cancer: A case study in Hangzhou City. Environ. Geochem. Hlth. 2018, 40, 2481-2490. [CrossRef]

29. Shao, S.; Hu, B.F.; Tao, Y.H.; You, Q.H.; Huang, M.X.; Zhou, L.Q.; Chen, Q.X.; Shi, Z. Comprehensive source identification and apportionment analysis of five heavy metals in soils in Wenzhou City, China. Environ. Geochem. Hlth. 2021, 1-24. [CrossRef]

30. Jaffar, S.T.A.; Chen, L.Z.; Younas, H.; Ahmad, N. Heavy metals pollution assessment in correlation with magnetic susceptibility in topsoils of Shanghai. Environ. Earth Sci. 2017, 76, 7. [CrossRef]

31. Gan, T.T.; Zhao, N.J.; Yin, G.F.; Ma, M.J.; Meng, D.S.; Fang, L.; Yang, R.F.; Liu, W.Q. A Review on Heavy Metal Pollution of Agricultural Land Soil in the Yangtze River Delta and Relevant Pollution Control Strategy. Chin. Eng. Sci. 2021, 23, 174-184.

32. Huang, Y.; Li, T.; Wu, C.; He, Z.; Japenga, J.; Deng, M.; Yang, X. An integrated approach to assess heavy metal source apportionment in peri-urban agricultural soils. J. Hazard. Mater. 2015, 299, 540-549. [CrossRef]

33. Zhou, J.; Feng, K.; Pei, Z.; Meng, F.; Sun, J. Multivariate analysis combined with GIS to source identifification of heavy metals in soils around an abandoned inustrial area, Eastern China. Ecotoxicology 2016, 25, 380-388. [CrossRef] [PubMed]

34. Lv, J.S. Multivariate receptor models and robust geostatistics to estimate source apportionment of heavy metals in soils. Environ. Pollut. 2019, 24, 72-83. [CrossRef] [PubMed]

35. Xie, X.F.; Wu, T.; Zhu, M.; Jiang, J.J.; Xu, Y.; Wang, X.H.; Pu, L.J. Comparison of random forest and multiple linear regression models for estimation of soil extracellular enzyme activities in agricultural reclaimed coastal saline land. Ecol. Indic. 2021, 120, 106925. [CrossRef]

36. Lu, R.K. Analytical Methods of Soil and Agricultural Chemistry; Agricultural Science \& Technology Press: Beijing, China, 1999.

37. Pan, L.B.; Ma, J.; Hu, Y.; Su, B.Y.; Fang, G.L.; Wang, Y.; Wang, Z.S.; Wang, L.; Xiang, B. Assessments of levels, potential ecological risk, and human health risk of heavy metals in the soils from a typical county in Shanxi Province, China. Environ. Sci. Pollut. Res. 2016, 23, 19330-19340. [CrossRef] [PubMed]

38. Huang, J.H.; Guo, S.T.; Zeng, G.M.; Li, F.; Gu, Y.L.; Shi, Y.H.; Shi, L.X.; Liu, W.C.; Peng, S.Y. A new exploration of health risk assessment quantification from sources of soil heavy metals under different land use. Environ. Pollut. 2018, 243, 49-58. [CrossRef] [PubMed]

39. US EPA. Integrated Risk Information System [R/OL]. 2011. Available online: http://www.epa.gov/iris/index.html (accessed on 7 December 2020).

40. Xu, S.J.; Zheng, N.; Liu, J.S.; Wang, Y.; Chang, S.Z. Geochemistry and health risk assessment of arsenic exposure to street dust in the zinc smelting district, Northeast China. Environ. Geochem. Health 2013, 35, 89-99. [CrossRef] [PubMed] 
41. Ministry of Ecology and Environment (MEE). Soil Environmental Quality Risk Control Standard for Soil Contamination of Agricultural Land (GB15618-2018). 2018. Available online: http://www.mee.gov.cn/ywgz/fgbz/bz/bzwb/trhj/201807/W020 190626595212456114.pdf (accessed on 25 December 2020).

42. Zhang, Y.Y.; Ma, J.; Wei, H.Y.; Shi, T.R. Heavy metals in typical farmland soils of Zhejiang Province: Levels, sources and ecological risks. Ecol. Environ. Sci. 2019, 28, 1233-1241.

43. Wang, S.; Cai, L.M.; Wen, H.H.; Luo, J.; Wang, Q.S.; Liu, X. Spatial distribution and source apportionment of heavy metals in soil from a typical county-level city of Guangdong Province, China. Sci. Total Environ. 2019, 655, 92-101. [CrossRef] [PubMed]

44. Charlesworth, S.; Everett, M.; Mc, C.R. A comparative study of heavy metal concentration and distribution in deposited street dusts in a large and a small urban area: Birmingham and Coventry, West Midlands, UK. Environ. Int. 2003, 29, 563-573. [CrossRef]

45. Huang, H.B.; Lin, C.Q.; Hu, G.R.; Yu, R.L.; Hao, C.L.; Chen, F.H. Source appointment of heavy metals in agricultural soils of the Jiulong River Basin based on positive matrix factorization. Environ. Sci. 2020, 41, 430-437.

46. Rachwal, M.; Magieral, T.; Wawer, M. Coke industry and steel metallurgy as the source of soil contamination by technogenic magnetic particles, heavy metals and polycyclic aromatic hydrocarbons. Chemosphere 2015, 138, 863-873. [CrossRef] [PubMed]

47. Liang, J.; Feng, C.T.; Zeng, G.M.; Gao, X.; Zhong, M.Z.; Li, X.D.; Li, X.; He, X.Y.; Fang, Y.L. Spatial distribution and source identification of heavy metals in surface soils in a typical coal mine city, Lianyuan, China. Environ. Pollut. 2017, 225, 681-690. [CrossRef] [PubMed]

48. Choppala, G.; Bolan, N.; Jin, H.P. Chapter two: Chromium contamination and its risk assessment in complex environmental settings. Adv. Agron. 2013, 120, 129-172.

49. Grezzi, G.; Ayuso, R.A.; De Vivo, B.; Lima, A.; Albanese, S. Lead isotopes in soils and groundwaters as tracers of the impact of human activities on the surface environment: The Domizio-Flegreo Littoral (Italy) case study. J. Geochem. Explor. 2011, 109, 51-58. [CrossRef]

50. $\mathrm{Hu}, \mathrm{Y} . \mathrm{N}$;; Cheng, H.F. Application of stochastic models in identification and apportionment of heavy metal pollution sources in the surface soils of a large-scale region. Environ. Sci. Technol. 2013, 47, 3752-3760. [CrossRef] [PubMed]

51. Yang, Y.; Christakos, G.; Guo, M.W.; Xiao, L.; Huang, W. Space-time quantitative source apportionment of soil heavy metal concentration increments. Environ. Pollut. 2017, 223, 560-566. [CrossRef] [PubMed]

52. Trujillo-Gonzalez, J.M.; Torres-Mora, M.A.; Keesstra, S.; Brevik, E.C.; Jimenez-Ballesta, R. Heavy metal accumulation related to population density in road dust samples taken from urban sites under different land uses. Sci. Total Environ. 2016, 553, 636-642. [CrossRef]

53. Cesari, D.; Amato, F.; Pandolfi, M.; Alastuey, A.; Querol, X.; Contini, D. An inter-comparison of PM 10 source apportionment using PCA and PMF receptor models in three European sites. Environ. Sci. Pollut. Res. 2016, 23, 15133-15148. [CrossRef] [PubMed]

54. Zeng, J.; Han, G.; Yang, K. Assessment and sources of heavy metals in suspended particulate matter in a tropical catchment, northeast Thailand. J. Clean. Prod. 2020, 265, 121898. [CrossRef]

55. Gholizadeh, M.H.; Melesse, A.M.; Reddi, L. Water quality assessment and apportionment of pollution sources using APCS-MLR and PMF receptor modeling techniques in three major rivers of South Florida. Sci. Total Environ. 2016, 566-567, 1552-1567. [CrossRef]

56. Khairy, M.A.; Lohmann, R. Source apportionment and risk assessment of polycyclic aromatic hydrocarbons in the atmospheric environment of Alexan-dria, Egypt. Chemosphere 2013, 91, 895-903. [CrossRef]

57. Stout, S.A.; Graan, T.P. Quantitative source apportionment of PAHs in sediments of little menomonee river, Wisconsin: Weathered creosote versus urban background. Environ. Sci. Technol. 2010, 44, 2932-2939. [CrossRef] [PubMed]

58. Wu, J.T.; Margenot, A.J.; Wei, X.; Fan, M.M.; Zhang, H.; Best, J.L.; Wu, P.B.; Chen, F.R.; Gao, C. Source apportionment of soil heavy metals in fluvial islands, Anhui section of the lower Yangtze River: Comparison of APCS-MLR and PMF. J. Soil Sediment. 2020, 20, 3380-3393. [CrossRef]

59. Zhao, H.R.; Xia, B.C.; Fan, C.; Zhao, P.; Shen, S.L. Human health risk from soil heavy metal contamination under different land uses near Dabaoshan Mine, Southern China. Sci. Total Environ. 2012, 417, 45-54. [CrossRef] [PubMed]

60. Dehghani, S.; Moore, F.; Keshavarzi, B.; Hale, B.A. Health risk implications of potentially toxic metals in street dust and surface soil of Tehran, Iran. Ecotoxicol. Environ. Saf. 2017, 136, 92-103. [CrossRef]

61. Shaheen, S.M.; Antoniadis, V.; Kwon, E.; Song, H.; Wang, S.L.; Hseu, Z.Y.; Rinklebe, J. Soil contamination by potentially toxic elements and the associated human health risk in geo- and anthropogenic contaminated soils: A case study from the temperate region (Germany) and the arid region (Egypt). Environ. Pollut. 2020, 262, 114312. [CrossRef] [PubMed]

62. DHAenC (Department of Health and Aging and enHealth Council). Environmental health risk assessment: Guidelines for assessing human health risks from environmental hazards. Canberra ACT 2012, 2, 94-95.

63. Tao, X.Q.; Shen, D.S.; Shentu, J.L.; Long, Y.Y.; Feng, Y.J.; Shen, C.C. Bioaccessibility and health risk of heavy metals in ash from the incineration of different e-waste residues. Environ. Sci. Pollut. Res. 2014, 22, 3558-3569. [CrossRef] [PubMed]

64. Chabukdhara, M.; Nema, A. Heavy metals assessment in urban soil around industrial clusters in Ghaziabad. India: Probabilistic health risk approach. Ecotoxicol. Environ. Saf. 2013, 87, 57-64. [CrossRef] [PubMed]

65. Ferreira-Baptista, L.; De Miguel, E. Geochemistry and risk assessment of street dust in Luanda, Angola: A tropical urban environment. Atmos. Environ. 2005, 39, 4501-4512. [CrossRef] 